\title{
MORPHOLOGICAL CHARACTERISTICS OF SKIN LESIONS IN CATTLE NATURALLY INFECTED WITH LUMPY SKIN DISEASE VIRUS IN SERBIA
}

\author{
VASKOVIĆ Nikola ${ }^{*}$, DEBELJAK Zoran ${ }^{1}$, VIDANOVIĆ Dejan ${ }^{1}$, ŠEKLER \\ Milanko $^{1}$, MATOVIĆ Kazimir ${ }^{1}$, ANIČIĆ Milan², MARINKOVIĆ Darko²
}
${ }^{1}$ Veterinary Specialistic Institute „Kraljevo”, Kraljevo, Serbia; ${ }^{2}$ Department of Pathology, Faculty of Veterinary Medicine, University of Belgrade, Belgrade, Serbia

(Received 15 November, Accepted 02 December 2019)

Lumpy skin disease (LSD) is a disease of cattle and domestic buffaloes caused by Capripoxvirus which can lead to significant economic losses. Until several years ago it was limited to Africa and the Middle East, but recently it was reported in Turkey (2013), Greece (2015), and in 2016 it spread to Bulgaria, North Macedonia, Albania, Montenegro and Serbia. The aim of this study was to determine the microscopic lesions in the skin of naturally infected animals, highlight their features and compare them to the findings of other authors. Gross lesions in the skin of cattle infected with Lumpy skin disease virus (LSDV) were manifested in the form of skin nodules which were round, raised, clearly circumscribed, firm and randomly distributed in the whole skin including the vulva and udder. Histopathological lesions included degeneration of epithelial cells, hyperkeratosis, spongiosis, and acanthosis present in $85.88 \%, 81.18 \%$, $84.71 \%$, and $80.0 \%$ of samples, respectively. Intracytoplasmic inclusion bodies were noted in keratinocytes of the stratum spinosum in $56.47 \%$ of samples, and in hair follicle cells and sebaceous glands epithelial cells in $45.88 \%$ of samples. Cutaneous lesions were in the form of inflammatory infiltrate present in the dermis and subcutis in $97.65 \%$ of samples. Since there are only a few literature data in this field, this study expands the knowledge relating to morphological alterations in LSD. Based on the characteristic microscopic lesions described in the present study, histopathology should be considered as a very useful method for the diagnosis of LSD.

Key words: Capripoxvirus, cattle, histopathology, Lumpy Skin Disease, natural infection

\section{INTRODUCTION}

Lumpy skin disease (LSD) is a viral disease of cattle and domestic buffaloes which causes significant economic losses. It is caused by Lumpy skin disease virus (LSDV), which belongs to the genus Capripoxvirus, within the subfamily Chordopoxvirinae of the family Poxviridae [1,2]. Hematophagous arthropods as mechanical and biological

\footnotetext{
*Corresponding author: e-mail: vaskovic@vsikv.com
} 
vectors have the most important role in the transmission of the disease [2-5]. The disease could possibly be transmitted by semen, milk, or contaminated food or water [2,6-8]. Intrauterine and iatrogenic transmission may also occur $[9,10]$.

The incubation period is usually 1-2 weeks, and morbidity rate may vary from 5-45 \% [11-13]. The characteristic clinical signs are: fever $\left(40-41{ }^{\circ} \mathrm{C}\right)$, excessive salivation, lachrymation and nasal discharge, depression, anorexia, decrease in milk yield, enlarged lymph nodes, and nodules in skin and in mucous membranes of the respiratory, alimentary and genital tract. Mortality is usually low, under $10 \%[2,5,12,13]$.

Skin nodules usually appear two to five days after the initial febrile response. They are randomly distributed, 10 to $50 \mathrm{~mm}$ in diameter, well circumscribed, firm, round and raised [2,14-16]. On cut section, nodules have a whitish-grey or reddish grey appearance, and involve the skin and subcutaneous tissues, occasionally the skeletal muscle. Skin lesions either resolve, become indurated or sequestrate to leave deep ulcers [16-18].

Depending on the stage of the disease, the following microscopical lesions are present in the skin: vasculitis with thrombosis and infarction resulted in edema and necrosis, perivascular fibroplasia, infiltration by macrophages, lymphocytes and eosinophils in the dermis and subcutis, ballooning degeneration, acanthosis, parakeratosis and hyperkeratosis in the epidermis, and eosinophilic intracytoplasmic inclusions (from $1 \mu \mathrm{m}$ to the size of the nucleus) in macrophages, keratinocytes, endothelial cells, pericytes, ductal and acinar epithelial cells of mucous and serous glands, as well as skeletal muscle cells and fibroblasts $[2,14,16]$.

Until several years ago LSD was limited to Africa and the Middle East. In 2013 it was reported in Turkey [19], in 2015 in Greece [20], and in 2016 it spread to Bulgaria, North Macedonia, Albania and Montenegro [21]. In June 2016, the first case of LSD in the southern part of Serbia was reported [22]. In the next four months the disease was spread to the central parts of Serbia, and a total number of 225 outbreaks were reported.

The aim of this study was to determine the microscopic lesions in the skin of naturally infected animals, highlight their features and compare them to the findings of other authors.

\section{MATERIAL AND METHODS}

During epizootic of 2016, suspected cattle of different breeds, mostly Simmental and domestic spotted cattle in the type of Simmental, of different age, and of both sex were clinically examined with special focus on macroscopic skin lesions. Animals with clinical symptoms of LSD were chosen for skin sampling. Representative samples of skin nodules were taken with sterile scalpels after application of local anesthetic and transported to the laboratory. 
Samples were homogenized on a Vortex Genie 2 device (Scientific Industries, USA) and DNA was extracted on Kingfisher mL device (Thermo Fisher Scientific) using the MagVet Universal Kit (LSI, Germany) following manufacturer's instructions. For specific detection of field strains of LSDV a Real Time PCR assay [23] was used. Reaction mixture contained $12.5 \mu$ Brilliant III Ultra-Fast QPCR Master Mix (Agilent, USA), $0.4 \mu \mathrm{M}$ forward primerLSD_KV_2_FTGGGATGATAACAACGTTTATG, 0.4 $\mu \mathrm{M}$ reverse primer LSD_KV_2_RACATTGTCATCCGGTAATGTA, $0.2 \mu \mathrm{M}$ probe LSD_KV2_Pro_fieldVIC-T'TACCACCTAATGATAGTGTTTATGATTTACCBHQ1, nuclease-free water up to $22.5 \mu \mathrm{l}$ and $2.5 \mu \mathrm{l}$ of extracted viral DNA. The reaction was performed in AriaMX instrument (Agilent, USA) using following parameters: $95{ }^{\circ} \mathrm{C}$ for $3 \mathrm{~min}$, and $45 \times 95{ }^{\circ} \mathrm{C}$ for $15 \mathrm{~s}$ and $60{ }^{\circ} \mathrm{C}$ for $30 \mathrm{~s}$.

Eighty five of collected skin samples, which were positive for the presence of LSDV genome, were fixed in 10\% neutral buffered formalin. After standard processing in the automated tissue processor, samples were embedded in paraffin blocks. Five $\mu \mathrm{m}$ thick sections were dewaxed in xylol, rehydrated through a series of ethanol of decreasing concentrations to distilled water, and stained with hematoxylin and eosin (HE).

The results of histochemical staining were analyzed by light microscope (BX51, Olympus Optical, Japan), and pictures were taken with Olympus Color View III ${ }^{\circledR}$ digital camera.

\section{RESULTS}

\section{Molecular confirmation of field strains of LSDV}

Skin biopsies of 85 animals were tested positive for the field strain of LSDV using qPCR specific assay.

\section{Macroscopic findings}

Skin nodules were round and raised, clearly circumscribed, firm, randomly distributed in the whole skin including the vulva and udder. The number of skin nodules varied from a few on the head and neck to several hundred on the whole body (Fig 1a,b). The size of nodules varied from $10 \mathrm{~mm}$ to $50 \mathrm{~mm}$. On the cut surface, the nodules were firm, whitish-grey, and they involved the skin and subcutaneous tissue. The surrounding subcutaneous tissue was often infiltrated with reddish-grey serous liquid. In several animals, skin ulcers were present in the place of erupted nodules (Fig 1c). The superficial lymph nodes were usually enlarged. Edema of the ventral body parts of some animals was present in some cases. Lachrymation, conjunctivitis, salivation and nasal discharge were often noted. Lesions on the hairless skin (muzzle, vulva and udder) were often in the form of well-circumscribed necrotic plaques $10-20 \mathrm{~mm}$ in diameter (Fig 1d,e,f). 

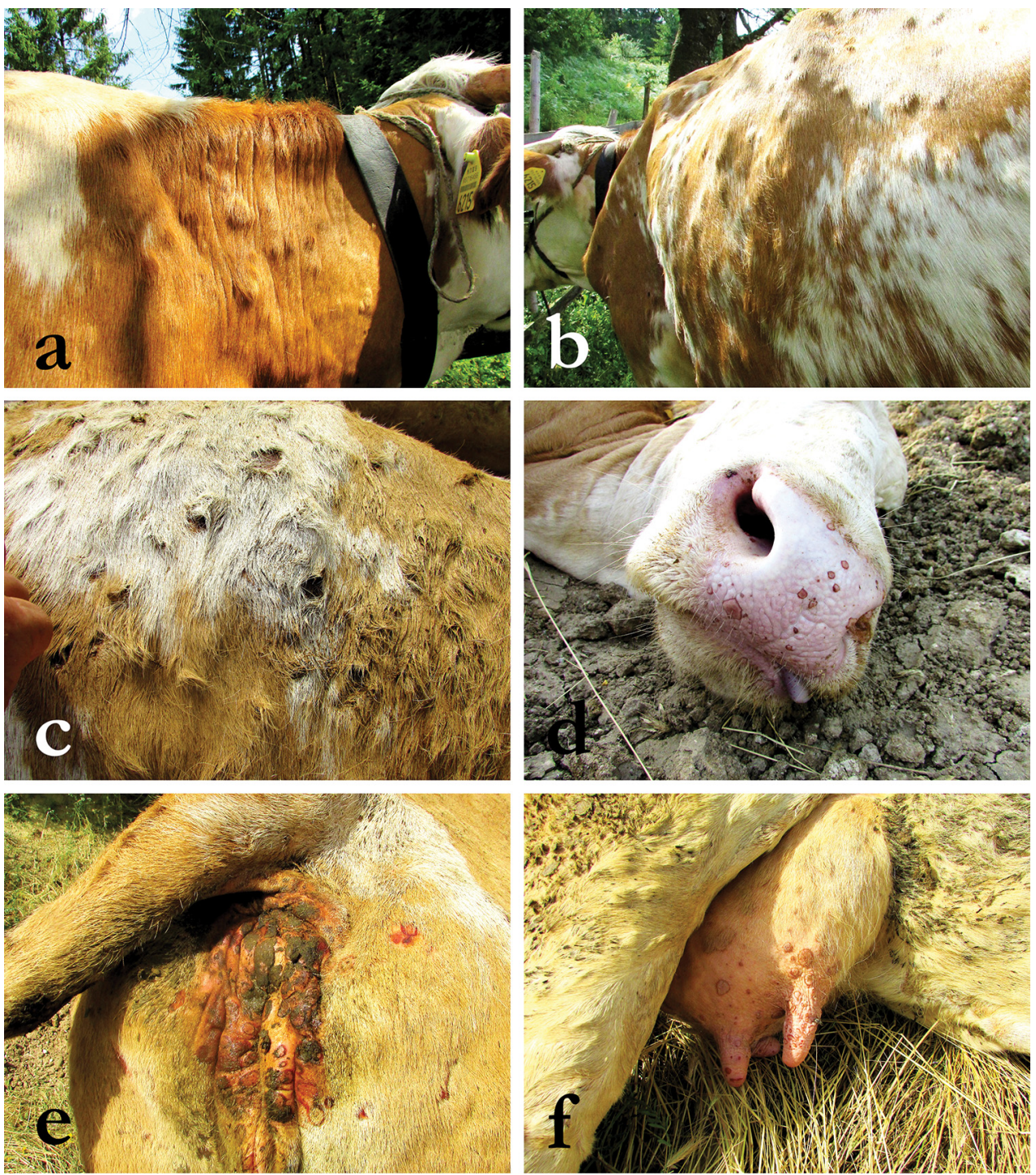

Figure 1. Macroscopic appearance of skin lesions of cattle with LSD; a) nodules on the neck; b) nodules on the trunk; c) ulcerated nodules on the trunk; d) circumscribed necrotic plaques on the muzzle; e) circumscribed necrotic plaques on the vulva; f) circumscribed necrotic plaques on the udder.

\section{Histopathological findings}

Hydropic degeneration of epithelial cells, vacuolization, spongiosis, parakeratosis, hyperkeratosis and acanthosis were seen in the epidermis (Fig 2a). Degeneration of epithelial cells was present in $68(85.88 \%)$ samples. Cells of stratum basale and stratum spinosum were swollen and contained cytoplasmic microvesicles which gave them a 
granular appearance, but sometimes large vacuoles in the epithelial cells were noted (Fig 2b). Spongiosis (intercellular edema) was present in 72 (84.71\%) samples (Fig 2c). A clear zone of edema was present between keratinocytes, and intercellular bridges were prominent. Hyperkeratosis was present in 69 (81.18\%) samples (Fig 2d). The stratum corneum was thickened and in the majority of samples squamous epithelial
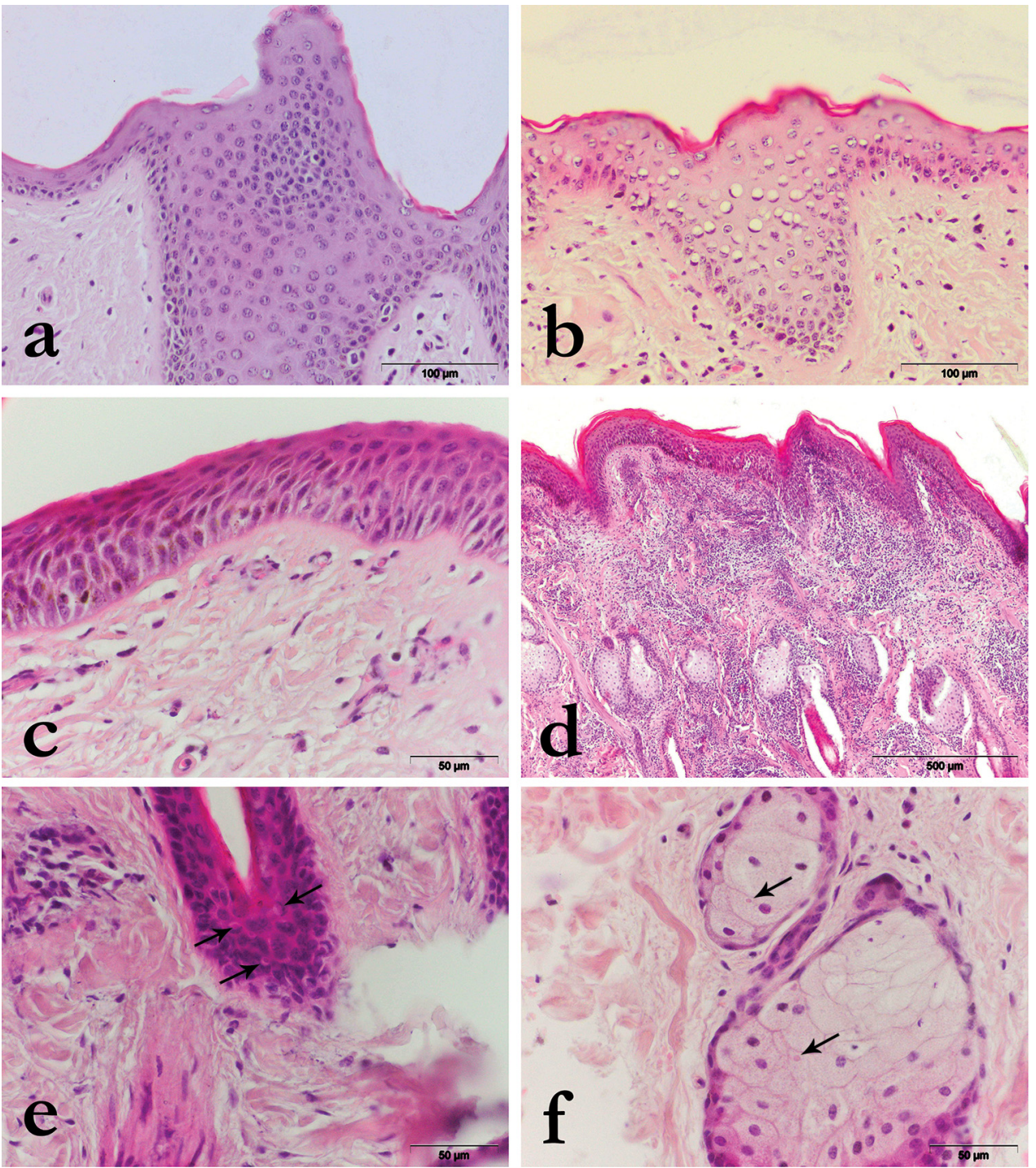

Figure 2. Histopathologic appearance of skin lesions of the cattle with LSD; a) epidermis with acanthosis; b) vacuolization of the epidermal cells; c) spongiosis and degenerative changes in the epidermis; d) inflammatory infiltrate, degenerative changes of the epidermal cells and hyperkeratosis; e) degenerative changes and intracytoplasmic inclusions (arrow) in the epidermal cells; f) degenerative changes and intracytoplasmic inclusions (arrow) in the sebaceous gland cells; HE. 
cells were anuclear (orthokeratosis), although nuclear squamous cells (parakeratosis) were also seen in some samples. In $68(80 \%)$ samples, acanthosis was noted. Focally, multiplication of keratinocytes and thickening of the stratum spinosum was present. It was often associated with hydropic degeneration of keratinocytes and spongiosis.

Cell infiltration, vasculitis, hyperemia, hemorrhages and necrosis were noted in the dermis (Fig 2d). Multifocal inflammatory infiltrate of varying intensity, was present in the dermis and subcutis in $83(97.65 \%)$ samples. Infiltrates mainly consisted of mononuclear cells, macrophages and lymphocytes, while plasma cells were noted in several samples.

Eosinophils were often noted in these infiltrates, and in several samples, neutrophils were seen. Mononuclear infiltrate was recorded in the wall of dermal and subcutaneous blood vessels in $26(30.59 \%)$ samples. Consequently, necrosis was present in 23 $(27.06 \%)$ and extravasation of erythrocytes was present in $20(23.53 \%)$ samples. Hyperemia was present in $23(27.06 \%)$ samples.

Hydropic degeneration of hair follicle cells and sebaceous gland cells was noted in $49(53.65 \%)$ samples (Fig 2e). Spongiosis of hair follicle cells and dilatation of sweat glands were seen in several samples. Intracellular hyaline degeneration (Zenker degeneration) of subcutaneous muscles was noted in $5(5.88 \%)$ samples. Myofibrils were homogenized, and their sarcoplasm was segmented.

Intracytoplasmic inclusion bodies were described in the keratinocytes of stratum spinosum in $48(56.47 \%)$ samples, and in hair follicle cells and sebaceous glands epithelial cells in 39 (45.88\%) samples (Fig 2 e,f). Inclusion bodies were eosinophilic, homogeneous, varied in size from $1 \mu \mathrm{m}$ to the size of the nucleus of the containing cell. In the cytoplasm of some cells, round to oval, well demarcated formations morphologically consistent with inclusion bodies that lacked eosinophilia were noted.

\section{DISCUSSION}

LSD is considered as economically important disease of cattle worldwide, especially in the Middle East and Africa. In the recent years several breakouts were reported: in Turkey in 2013 [19], in Greece in 2015 [20] and in Bulgaria, North Macedonia, Albania and Montenegro in 2016 [21]. In 2016, the disease caused great economic losses in Serbia due to stamping out of 709 infected and potentially infected cattle and vaccination of healthy population [22]. Due to mass vaccination the epizootic in Serbia was stopped by October 2016 when the last case of LSD was reported. In this study, we describe the macroscopic and histopathologic characteristics of skin lesions in cattle naturally infected with LSDV.

According to Babiuk et al. [11] skin is the most susceptible tissue for the replication of LSDV and because of that it represents the most relevant sample for laboratory diagnosis. Also, characteristic microscopic features develop in the skin tissue during viral infection making it a suitable material for pathomorphological examination. 
The most characteristic macroscopic lesions in the current study were multifocal skin nodules which were round (sometimes merging to form plaques), raised, $10-50 \mathrm{~mm}$ in diameter, occasionally with erected hair, clearly circumscribed and firm, sometimes with a central necrotic zone. On the cut surface, nodules were firm, whitish-grey, and involved skin and subcutaneous tissue. These findings are consistent with literature data $[14,16]$. Well-circumscribed necrotic plaques on the hairless skin of muzzle and udder, 10-20 $\mathrm{mm}$ in diameter, noted in the present study are similar to those described by Coetzer et al. [2].

Despite the fact that domestic buffaloes were present in the same stables with cattle, characteristic lesions were found only in cattle. This can be explained due to the fact that the domestic buffaloes appeared to be less susceptible to the LSDV [14,24].

The most prominent histopathologic lesion were mononuclear inflammatory infiltrates of varying intensity in the dermis and subcutis which were present in $97.65 \%$ of samples.

The infiltrate mainly consisted of mononuclear cells - macrophages, lymphocytes and occasionally plasma cells. In contrast to the findings of Prozesky and Barnard [16], but similar to the findings of Tageldin et al. [25], eosinophils were often noted in these infiltrates, which can be attributed to a different strain of the virus or stage of the disease. Vasculitis, characterized by the mononuclear infiltrate in the wall of dermal and subcutaneous blood vessels was noted in $30.59 \%$ of cases. Due to Prozesky and Barnard [16] vasculitis and thrombosis have the central role in the pathogenesis of the skin lesions in cattle infected with LSDV. El-Neweshy et al. [26] assumed that vasculitis is immune-mediated. These vascular lesions consequently led to necrosis and hemorrhage in the dermis. According to literature data in the acute phase of the disease vasculitis and thrombosis result in consequent necrosis. In the chronic phases fibroplasia and perivascular round cell cuffs have been described [16], but these findings were not present in this study, probably due to the stage of the nodules sampled for the investigation, because for the purpose of laboratory diagnostics only nodules which last appeared have been sampled.

Hydropic degenerative changes were the most prominent finding on the epidermal and adnexal (hair follicles, sebaceous and sweat gland) epithelial cells. Epithelial cells of stratum basale and stratum spinosum were swollen and contained cytoplasmic microvesicles which gave them a granular appearance. Beside degenerative changes spongiosis characterized by a clear zone of intercellular edema between keratinocytes, and prominent intercellular bridges were present. Also, most of the samples showed hyperkeratotic lesions in the form of both orthokeratotic and parakeratotic hyperkeratosis. Similar findings were reported by other authors $[14,16]$.

Intracytoplasmic eosinophilic, homogeneous inclusion bodies which varied in size from $1 \mu \mathrm{m}$ to the size of the nucleus were noted in keratinocytes of stratum spinosum, hair follicle cells and sebaceous glands epithelial cells. These findings are consistent with the findings of other authors [14-17,24,25,27,28]. Some authors report inclusion 
bodies in macrophages, endothelial cells, pericytes, skeletal muscle cells and fibroblasts which were not noted in the samples from our study.

Hyaline degeneration and necrosis, characterized by homogenized appearance of myofibrils and segmentation of sarcoplasm of subcutaneous muscles was noted in only $5.88 \%$ of samples from this study, while Amin et al. reported much higher percentage of this lesion [28]. This can be explained by the fact that the samples for our study were taken in the acute and subacute stage of the disease and also muscle tissue lacked in some samples.

In conclusion, since there are only a few literature data in this field, this study expands the knowledge relating to morphological alterations in LSD. Multifocal inflammatory infiltrate was the most prominent finding in the skin of the cattle infected with LSDV, followed by the degeneration of epithelial cells, acanthosis, spongiosis, hyperkeratosis, while the inclusion bodies located in keratinocytes, hair follicle cells and sebaceous glands epithelial cells were found in approximately half of skin samples. Based on the characteristic microscopic lesions described in the present study, histopathology should be considered as a very useful method for the diagnosis of LSD.

\section{Acknowledgements}

Authors would like to thank Aleksandar Tomić for his technical assistance.

\section{Authors' contributions}

$\mathrm{VN}$ and MD designed the study and interpreted results. VD, ŠM and MK were involved in sampling and carried out the molecular testing. VN, DZ, AM and MD carried out gross and histopathological examination. All authors read and approved the final manuscript.

\section{Declaration of conflicting interests}

The author(s) declared no potential conflicts of interest with respect to the research, authorship, and/or publication of this article.

\section{REFERENCES}

1. Buller RM, Arif BM, Black DN, Dumbell KR, Esposoto JJ, Lefkowitz EJ, McFadden G, Moss B, Mercer SS, Moyer Rw, Skinner MA, Tripathy DN: Poxviridae, 2005. In: Faquet CM, Mayo MA, Maniloff J, Desselberger U, Ball LA (eds), Virus Taxonomy: Eight Report of the International Committee on the Taxonomy of Viruses. Elsevier Academic Press, 117-113.

2. Coetzer JAW ,Tuppurainen E, Babiuk S, Wallace DB: Lumpy skin disease. In Coetzer JAW, Thomson GR, Maclachlan NJ, Penrith ML (Eds): Infectious Diseases of Livestock 2018, Anipedia.

3. Chihota CM, Rennie LF, Kitching RP, Mellor PS: Attempted mechanical transmission of lumpy skin disease virus by biting insects. Medical and Veterinary Entomology 2003, 17:294-300. 
4. Tuppurainen ESM, Oura CAL:Review: lumpy skin disease: an emerging threat to Europe, the Middle East and Asia. Transbound Emerg Dis 2012, 59(1):40-48.

5. Tuppurainen ESM, Venter EH, Shisler JL, Gari G, Mekonnen GA, Juleff N, ... Babiuk LA: Review: Capripoxvirus, diseases: Current status and opportunities for control. Transbound Emerg Dis 2015, 64:729-745.

6. Annandale CH, Holm DE, Ebersohn K, Venter EH: Seminal transmission of lumpy skin disease virus in heifers. Transbound Emerg Dis 2013, 61:443-448.

7. Irons PC, Tuppurainen ESM, Venter EH: Excretion of lumpy skin disease virus in bull semen. Theriogenology 2005, 63:1290-1297.

8. Tuppurainen ESM, Venter EH, Coetzer JAW:The detection of lumpy skin disease virus in samples of experimentally infected cattle using different diagnostic techniques. Onderstepoort Journal of Veterinary Research 2005, 72(2):153-164.

9. FAO : Sustainable prevention, control and elimination of lumpy skin disease - Eastern Europe and the Balkans. FAO Animal Production and Health Position Paper 2017.

10. Rouby S, Aboulsoud E: Evidence of intrauterine transmission of lumpy skin disease virus. Veterinary Journal 2016, 209:193-195.

11. Babiuk S, Bowden TR, Boyle DB, Wallace DB, Kitching RP: Capripoxviruses: an emerging worldwide threat to sheep, goats and cattle. Tranbound Emerg Disease 2008, 55(7): 263272.

12. Babiuk S, Bowden TR, Parkyn G, Dalman B, Manning J, Neyfeld J, Embury-Hyat C, Copps J, Boyle DB: Quantification of Lumpy Skin Disease Virus Following Experimental Infection in Cattle. Transbound Emerg Dis 2008, 55:299-307.

13. Carn VM, Kitching RP:The clinical response of cattle experimentally infected with lumpy skin disease (Neethling) virus. Archives of Virology 1995, 140:503-513.

14. Ali AA; Esmat M Attia H, Selim A, Abdel-Hamid YM:Clinical and pathological studies on lumpy skin disease in Egypt. Vet Rec 1990, 127(22):549-550.

15. Neamat-Allah ANF: Immunological, hematological, biochemical, and histopathological studies on cows naturally infected with lumpy skin disease. Veterinary World 2015, 8(9):1131-1136.

16. Prozesky L, Barnard BJH: A study of the pathology of lumpy skin disease in cattle. Onderstepoort J Vet Res 1982, 49:167-175.

17. Body M, Singh KP, Hussain MH, Al-Rawahi A, Al-Maawali M, Al-Lamki K, Al-Habsy S: Clinico-Histopathological Findings and PCR Based Diagnosis of Lumpy Skin Disease in the Sultanate of Oman. Pakistan Veterinary Journal 2012, 32(2): 206-210.

18. Weiss KE: Lumpy Skin Disease Virus. Virology Monographs 1968, 3:111-131.

19. Wainwright S, El Idrissi A, Mattioli R, Tibbo M, Njeumi F, Raizman E:Emergence of lumpy skin disease in the Eastern Mediterranean Basin countries. Empress Watch 2013, 29:1-6.

20. Tasioudi KE, Antoniou SE, Iliadou P, Sachpatzidis A, Plevraki E, Agianniotaki EI, Fouki C, Mangana-Vougiouka O, Chondrokouki E, Dile C: Emergence of Lumpy Skin Disease in Greece. Tranbound Emerg Dis 2016, 63:260-265.

21. European Food Safety Authority (EFSA): Lumpy skin disease:I.Data collection and analysis. EFSA Journal 2017, 15(4):4773.

22. Manić M, Stojiljković M, Petrović M, Nišavić J, Bacić D, Petrović T, Vidanović D, Obrenović S: Epizootic features and control measures for lumpy skin disease in south-east Serbia in 2016. Transbound Emerg Dis 2019, 66:2084-2099. 
23. Vidanović D, Šekler M, Petrović T, Debeljak Z, Vasković N, Matović K, Hoffman B:Realtime PCR assays for the specific detection of field Balkan strains of lumpy skin disease virus. Acta Veterinaria 2016, 66:444-454.

24. Ahmed AM, Dessouki AA: Abattoir-Based Survey and Histopathological Findings of Lumpy Skin Disease in Cattle at Ismailia Abattoir. International Journal of Bioscience, Biochemistry and Bioinformatics 2013, 3:372-375.

25. Tageldin MH, Wallace DB, Gerdes GH, Putterill JF, Greyling RR, Phosiwa MN, Al Busaidy RM, Al Ismaaily SI: Lumpy skin disease of cattle: An emerging problem in the Sultanate of Oman. Trop Anim Health Prod 2014, 46(1):241-246.

26. El-Neweshy MS, El-Shemey TM, Youssef SA: Pathologic and immunohistochemical findings of natural lumpy skin disease in Egyptian cattle. Pakistan Veterinary Journal 2013, 33(1):60-64.

27. Abdallah FM, El Damaty HM, Kotb GF: Sporadic cases of lumpy skin disease among cattle in Sharkia province, Egypt: Genetic characterization of lumpy skin disease virus isolates and pathological findings. Veterinary World 2018,11:1150-1158.

28. Amin A, El-Nahas E, El-Mashed AE: Pathological and Virological Studies on an Outbreak of Lumpy Skin Disease among Cattle in Kalubia Governorate-Egypt. Journal of Advanced Veterinary Research 2015, 5:165-175.

\title{
MORFOLOŠKE KARAKTERISTIKE PROMENA U KOŽI GOVEDA PRIRODNO INFICIRANIH VIRUSOM NODULARNOG DERMATITISA U SRBIJI
}

\author{
VASKOVIĆ Nikola, DEBELJAK Zoran, VIDANOVIĆ Dejan, ŠEKLER Milanko, \\ MATOVIĆ Kazimir, ANIČIĆ Milan, MARINKOVIĆ Darko
}

Nodularni dermatitis (ND) je bolest goveda i domaćih bivola izazvana Capripoxvirus-om koja može da dovede do značajnih ekonomskih gubitaka. Do pre nekoliko godina bila je ograničena na Aziju i Bliski Istok, ali je nakon toga prijavljena i u Turskoj (2013) i Grčkoj (2015), da bi se 2016. godine proširila na Bugarsku, Severnu Makedoniju, Albaniju, Crnu Goru i Srbiju. Cilj ovog istraživanja bio je utvrđivanje mikroskopskih promena na koži prirodno inficiranih životinja, isticanje njihovih karakteristika i upoređivanje sa nalazima drugih autora. Makroskopske promene na koži goveda inficiranih virusom nodularnog dermatitisa manifestovale su se u formi čvorova koji su bili okrgli, uzdignuti, jasno ograničeni, čvrsti i nasumično raspoređeni po celoj koži, uključujući stidnicu i vime. Histopatološke promene su bile u formi degeneracije epitelijalnih ćelija, hiperkeratoze, spongioze i akantoze, prisutne redom u 85,88\%, 81,18\%, $84,71 \%$, i 80,0\% uzoraka. Intracitoplazmatske inkluzije su primećene u keratinocitima stratum spinosum-a u 56,47\% uzoraka, a u ćelijama folikula dlake i epitelnim ćelijama lojnih žlezda u 45,88\% uzoraka. Kožne promene bile su u obliku zapaljenskog infiltrata prisutnog u dermisu i subkutisu u 97,65\% uzoraka. S obzirom da u ovoj oblasti postoji malo literaturnih podataka, ova studija proširuje saznanja koja se odnose na morfološke promene kod ND. Na osnovu karakterističnih mikroskopskih promena opisanih u ovoj studiji, histopatologiju treba smatrati vrlo korisnom metodom za dijagnozu ND. 